\title{
Controlled trial of enalapril in congestive cardiac
} failure

\author{
BARRY P McGRATH, LEONARD ARNOLDA, P GEOFFREY MATTHEWS, \\ BRUCE JACKSON, GARY JENNINGS, * HO KIAT, ^ COLIN I JOHNSTON \\ From Monash University Department of Medicine, Prince Henry's Hospital, Melbourne, Victoria and ${ }^{\star} B a k e r$ \\ Institute for Medical Research, Prahran, Victoria, Australia
}

SUMMARY Twenty five patients with chronic congestive cardiac failure had enalapril $(n=13)$ or placebo $(n=12)$ added to their existing regimen of digoxin and frusemide in a randomised double blind trial. Four hours after the first $5 \mathrm{mg}$ dose, the enalapril group showed significant falls in blood pressure, heart rate, and concentrations of plasma angiotensin II, angiotensin converting enzyme, and noradrenaline. During the 12 week trial heart failure became worse in one enalapril treated patient $(8 \%)$ and in seven placebo treated patients $(58 \%)$. There were no significant changes in cardiac ejection fraction or exercise duration in either group. Plasma noradrenaline response to graded exercise and maximum exercise rate-pressure product were significantly reduced after four and 12 weeks of active treatment but unchanged with placebo treatment. There was a sustained increase in plasma potassium and a slight rise in plasma creatinine in the enalapril group. Plasma concentrations of the active drug, enalaprilate, were dose related and log enalaprilate correlated significantly with percentage of plasma angiotensin converting enzyme activity $(r=-0.66)$. Enalapril was well tolerated and produced no adverse effects. The drug appears to be superior to placebo and offers considerable promise for the treatment of this condition.

Captopril, the first of the orally active angiotensin converting enzyme inhibitors, has been shown in many open trials to relieve symptoms of congestive cardiac failure and improve cardiac haemodynamics, functional capacity, and exercise tolerance..$^{1-9}$ The beneficial effects of captopril have recently been confirmed in a double blind trial in which captopril was compared with placebo. ${ }^{10}$

Short term studies have largely been used to compare the effects of captopril with other vasodilators. ${ }^{1112}$ These have shown captopril to be at least as effective as hydralazine and prazosin. Both of these drugs, however, appear to have limited long term efficacy. ${ }^{13-15}$ Tolerance or resistance to these other vasodilators is in part due to activation of the renin-angiotensin aldosterone system with consequent fluid retention. Angiotensin converting enzyme inhibitors, by blocking the formation of

Requests for reprints to Dr B P McGrath, Monash University Department of Medicine, Prince Henry's Hospital, St Kilda Road, Melbourne 3004, Victorịa, Australia.

Accepted for publication 17 June 1985 angiotensin II could prevent this secondary hyperaldosteronism and might avoid the development of tolerance. Reports that prolonged treatment with captopril produces sustained improvement for up to two years accord with this postulated effect. ${ }^{4-9}$

Enalapril is a newer orally active angiotensin converting enzyme inhibitor. It has some potential advantages over captopril since it is long acting, apparently has few side effects, and concentrations of the active drug can be measured in blood. ${ }^{1617} \mathrm{We}$ examined the short term and long term effects of enalapril in patients with congestive heart failure in a double blind placebo controlled study. Response to therapy was determined by clinical assessment and measurements of exercise duration and catecholamine response to exercise. We also measured plasma concentrations of the active drug, enalaprilate, during long term treatment and related these to plasma concentrations of angiotensin converting enzyme activity.

\section{Patients and methods}

Twenty five patients with stable, moderate to severe 
congestive heart failure (New York Heart Association functional class II or III) participated in the study which was approved by the ethics committees of Prince Henry's and Prince Alfred's Hospitals. The cause of the heart failure was ischaemic heart disease in 18 (including one patient with an aortic valve replacement) and cardiomyopathy in seven (four idiopathic, three alcoholic).

To qualify for entry to the study, each patient gave informed consent and was stable on digoxin and frusemide. Their exercise capacity was limited to stage III, but was less than stage IX of an exercise test with a modified Naughton protocol. In addition, all patients had left ventricular ejection fractions less than $40 \%$. General exclusions included patients with right sided heart failure due to pulmonary disease, surgically correctable aortic valve or congenital heart disease, recent unstable angina or myocardial infarction within the previous four months, and those in whom other antihypertensive agents, potassium sparing diuretics, inotropes, or vasodilators could not be withdrawn. Once the study entry criteria had been satisfied, the patients were required to remain clinically stable for two weeks on the same doses of digoxin and frusemide. Before entry into the study 19 patients had been receiving other vasodilator therapy (hydralazine, prazosin). This therapy was discontinued for at least two weeks before the start of study. Ten patients had also been receiving long acting nitrates which were withdrawn in seven, but in three patients nitrate paste was continued to control angina. The same dose was used throughout the trial for these three patients, two of whom were assigned to the enalapril group and one to the placebo group. Potassium supplements were discontinued in the week before the trial started. Patients were randomised in a double blind manner to receive, in addition to the previous doses of digoxin and frusemide, either enalapril $5 \mathrm{mg}$ twice a day or a matching placebo. Patients were observed for at least four hours after the first dose and subsequently attended the clinic once a week for the next six weeks and then once a fortnight for a further six weeks. Dosage of enalapril or placebo was kept constant for the first four weeks after which the dose was increased during the study if there was no increase in exercise capacity, but the doses of digoxin and frusemide remained constant. The clinical characteristics of the patients are shown in Table 1.

\section{ASSESSMENT}

At each clinic visit patients had a complete clinical cardiovascular assessment. Each patient was specifically questioned about shortness of breath and fatigue which were graded $0-4$ ( 0 , none; 1 , walking up slope or stairs; 2, walking on level; 3 , minor exertion such as dressing; 4, at rest). Improvement or deterioration was indicated by a change, a decrease or an increase respectively, in symptom score. Body weight and resting supine blood pressure and heart rate were recorded, as were specific signs of heart failure (jugular venous pressure, peripheral oedema, additional heart sounds, basal lung crepitations, and hepatomegaly). Patients were asked about possible drug side effects. Finally an overall assessment was made by the examining physician of the patient's functional cardiac status based on the New York Heart Association classification (I, uncompromised, II, slightly compromised, III, moderately compromised, IV, severely compromised). ${ }^{18}$

Blood samples were taken at each visit for measurement of haemoglobin, white blood cell count and differential count, blood urea, plasma

Table 1 Clinical data for the enalapril and placebo groups

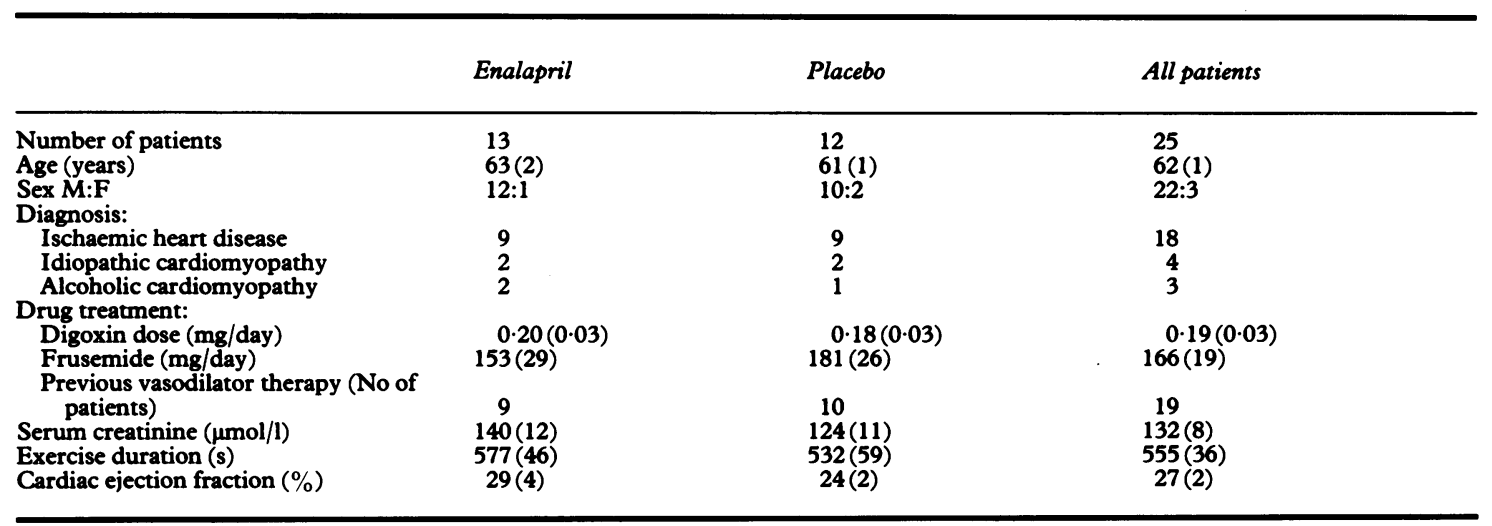


creatinine, and plasma electrolytes. Chest radiography and electrocardiography were performed at the initial visit and at the end of 12 weeks' treatment.

Ejection fraction was measured serially by echocardiography in nine patients and serially by gated blood pool scan in eight patients. Studies were performed during the pretreatment stabilisation period (week 0 ) and after four and 12 weeks during the double blind treatment phase. Echocardiographic examination was carried out after at least 10 minutes' rest in the left lateral position. Transducer position and echocardiographic gain were adjusted to obtain optimal recordings of left ventricular dimensions in the short axis. In all cases repeat echocardiograms were obtained with the patient in the same position as for the baseline study. Left ventricular end diastolic dimension was measured at the peak of the $R$ wave of the electrocardiograph and end systolic dimension at the time of the peak anterior motion of the left ventricular posterior wall. Left ventricular ejection fraction was derived from left ventricular end diastolic and end systolic dimensions. ${ }^{19}$ In eight patients ejection fraction was measured sequentially by gated blood pool scanning by the equilibration method after an intravenous injection of 740-945 $\mathrm{mBq}$ of technetium-99m tracer. ${ }^{20}$

Patients were withdrawn from the trial as treatment failures if there was evidence of worsening heart failure, defined as a change to a higher functional class of the New York Heart Association, requiring therapeutic intervention not permitted by the protocol. They could also be withdrawn for suspected adverse reactions, concurrent illness, or at their own request.

\section{EXERCISE TESTS}

Exercise stress tests were performed on the first and last days of the two week stabilisation period on digoxin and frusemide and after four and 12 weeks of the double blind phase of the study. The exercise was performed on a treadmill at least two hours after the morning dose of medication. The patients were familiarised with the procedure before entry to the study. The exercise consisted of consecutive two minute periods and began at a speed of one mile per hour on the level (stage I), increasing to two miles per hour for the next two minutes (stage II). Stages III-V were also at two miles per hour at slopes of $3.5^{\circ}, 7.0^{\circ}$, and $10.5^{\circ}$ and stages VI-VIII at three miles per hour at slopes $7.5^{\circ}, 10.0^{\circ}$, and $12.5^{\circ}$ respectively $(1 \mathrm{mph}=1.6 \mathrm{~km} / \mathrm{h})$. Exercise was increased in each patient provided there was no fall in blood pressure, no ventricular tachyarrhythmia, and no heart block, until symptoms of breathlessness or fatigue limited further increase. The electrocardiogram was monitored continuously and blood pressure was measured at rest and at the end of each workload by means of a mercury sphygomanometer. In 18 patients (10 enalapril, eight placebo treated) blood was taken from a forearm vein just before exercise, at the end of each exercise stage, and 15 minutes after the end of the exercise test for subsequent analysis of plasma catecholamines. All samples were taken while the patient was standing.

MEASUREMENTS OF CONCENTRATIONS OF

PLASMA HORMONES, ANGIOTENSIN

CONVERTING ENZYME ACTIVITY, AND

ENALAPRILATE

In 18 patients (10 enalapril treated, eight placebo

Table 2 Short term effects of enalapril treatment and placebo in patients with congestive cardiac failure

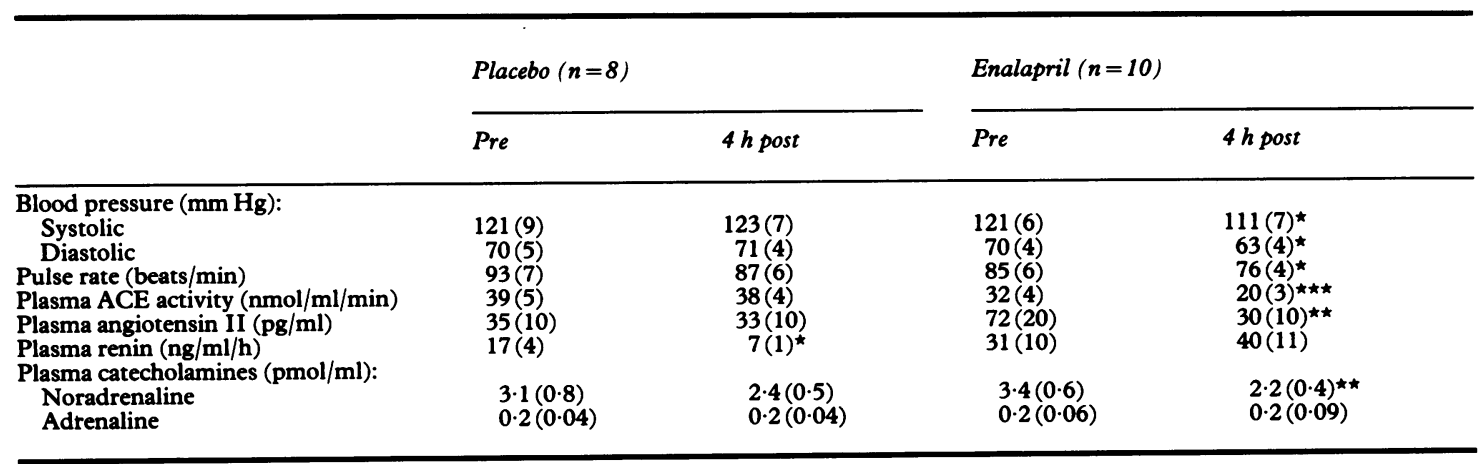

All measurements performed after patient had been seated comfortably for 20 minutes. Pre, pretreatment and $4 \mathrm{~h}$ post, 4 hours after first oral dose $(5 \mathrm{mg})$ of placebo or enalapril. ${ }^{\star} \mathrm{p}<0.05 ;{ }^{\star \star} \mathrm{p}<0.01 ;{ }^{\star \star \star} \mathrm{p}<0.001$ (paired $\mathrm{t}$ test). ACE, angiotension converting enzyme. Conversion: catecholamines: $1 \mathrm{pmol} / \mathrm{ml}=1 \mathrm{nmol} / 1$.

Conversion: traditional units to SI-Angiotensin II: $1 \mathrm{pg} / \mathrm{ml}=0.956 \mathrm{pmol} / 1$. Renin: $1 \mathrm{ng} / \mathrm{ml} / \mathrm{h}=0.771 \mathrm{nmol} / 1 / \mathrm{h}$. 
treated patients) studied at the one centre (Prince Henry's Hospital) venous blood was collected immediately before and then four hours after the initial $5 \mathrm{mg}$ enalapril or placebo tablet. Four hours was chosen since this was when the fall in blood pressure was greatest and enalaprilate concentrations were highest in a group of patients with essential hypertension. ${ }^{21}$ Subsequent blood samples were taken every two weeks during long term treatment four to five hours after the morning dose. Concentrations of the following hormones were measured in these blood samples: plasma adrenaline and noradrenaline by radioenzymatic assay ${ }^{22}$ and plasma renin concentration and angiotensin II by radioimmunoassay. ${ }^{2324}$ Concentrations of plasma angiotensin converting enzyme activity was measured by the method of Cushman and Cheung ${ }^{25}$ and blood concentrations of the active drug were determined by a radioimmunoassay. ${ }^{17}$

\section{STATISTICAL ANALYSIS}

Results are expressed as means and standard error of the mean. Analysis of results at different times for either placebo or enalapril treated groups was by analysis of variance as described by Snedecor and Cochran. ${ }^{26}$ Within group comparisons were made by paired $t$ test and comparisons between placebo and enalapril treated groups by the Wilcoxon rank test. ${ }^{26}$

\section{Results}

The two groups were well matched for age, sex (predominantly male), underlying heart disease, and drug therapy. Pretreatment concentrations of serum creatinine, exercise time, and cardiac ejection fraction were not significantly different in the two groups (Table 1).

SHORT TERM EFFECTS OF A SINGLE ORAL DOSE OF ENALAPRIL VERSUS PLACEBO

The blood pressure, pulse rate, plasma angiotensin converting enzyme activity, and hormonal responses to the first $5 \mathrm{mg}$ tablet of either enalapril or placebo are shown in Table 2. One patient in the enalapril group experienced a mild symptomatic hypotensive response which required no specific treatment. There were no other adverse effects recorded. The placebo treated group showed no change in blood pressure or pulse rate. In contrast after enalapril there was a significant fall in diastolic blood pressure $(70(4)$ to $63(4) \mathrm{mm} \mathrm{Hg}, \mathrm{p}<0.05)$ and pulse rate (85(6) to 76(4) beats per minute, $p<0.05$ ). Evidence for angiotensin converting enzyme inhibition in the enalapril treated group included significant falls in plasma angiotensin converting enzyme activity $(p<0.001)$ and plasma angiotensin II $(p<0.01)$. Plasma renin concentrations fell in the placebo group but increased in the enalapril group. Mean plasma noradrenaline concentration fell in both groups but the fall was significant only for the enalapril treated group. There were no significant changes in plasma adrenaline.

\section{LONG TERM EFFECTS OF ENALAPRIL VERSUS PLACEBO}

There were no significant adverse reactions reported by patients in either group. Body weight did not change significantly over the period of study in the two groups.

Symptoms improved in the enalapril treated group whereas the placebo treated group showed a deterioration. This was shown by an analysis of the changes in fatigue, breathlessness, and New York Heart Association functional class over 12 weeks of treatment (Table 3 ). In the placebo group seven of 12 patients had worsening of heart failure with a change to a higher New York functional class and five of these patients had to be withdrawn from the trial. All five had progressed to functional class IV and required changes in their treatment to control symptoms. Of the 13 patients in the active treatment group, two patients were withdrawn, one after 4 weeks because of worsening heart failure and one

Table 3 Changes in fatigue, shortness of breath, and New York Heart Association functional class after 12 weeks' treatment
Improved
No change
Deterioration

\begin{tabular}{llll}
\hline Fatigue: & & & \\
Placebo & 1 & $6(2)$ & $5(3)$ \\
Enalapril & $8(1)$ & 4 & $1(1)$ \\
Shortness of breath: & 2 & $3(1)$ & $7(4)$ \\
Placebo & $11(1)$ & 1 & $1(1)$ \\
Enalapril & 1 & 4 & $7(5)$ \\
NYHA functional class: & $9(1)$ & 3 & $1(1)$ \\
Placebo & Enalapril & & \\
\hline
\end{tabular}

NYHA, New York Heart Association.

The numbers in parentheses refer to patients withdrawn during the course of the study (between 4-12 weeks). 
after 6 weeks at his own request and despite clinical improvement in breathlessness, fatigue, and functional class (Table 3 ). The remaining 11 patients in the enalapril group showed either improvement (eight) or no change (three) in their functional classification. The difference between the groups for worsening heart failure was significant (placebo $7 / 12$ vs enalapril $1 / 13, \chi^{2}=7.4, p<0.01$ ).

There were no significant changes in cardiac ejection fraction at 4 weeks for either the enalapril (0 vs 4 weeks, $29(4 \%)$ vs $30(5 \%), n=9, p>0 \cdot 1)$ or the placebo groups ( 0 vs 4 weeks, $24(2 \%$ ) vs $23(3 \%$ ), $\mathrm{n}=8, \mathrm{p}>0 \cdot 1)$. Nor was there a significant change in cardiac ejection fraction after 12 weeks' treatment $(0$ vs 12 weeks: enalapril $25(2 \%)$ vs $25(4 \%), n=8$, p $>0 \cdot 1$; placebo $26(3 \%)$ vs $24(4 \%), n=5, p>0 \cdot 1)$. The transverse diameter of the heart was measured from chest $x$ rays taken before treatment and after 12 weeks' treatment or withdrawal from the study. No significant changes in this measurement were observed from either enalapril (18.1(0.5) to $17 \cdot 4(0 \cdot 6)$ $\mathrm{cm}, \mathrm{n}=11, \mathrm{p}>0.1)$ or placebo treatment $(17 \cdot 0(0 \cdot 6)$ to $17 \cdot 4(0 \cdot 7) \mathrm{cm}, \mathrm{n}=11, \mathrm{p}>0 \cdot 1)$.

In the placebo treated group after 4 weeks of treatment there were no significant changes in blood pressure, plasma angiotensin II concentration, or plasma angiotensin converting enzyme activity (Fig. 1). In contrast, patients in the enalapril treated group had a sustained fall in blood pressure and angiotensin II concentrations. Angiotensin converting enzyme activity which had shown an acute fall four hours after the first dose tended to return towards control concentrations with long term treatment.

HEART RATE, BLOOD PRESSURE, AND CATECHOLAMINE RESPONSES TO EXERCISE

All patients were able to exerise on the treadmill
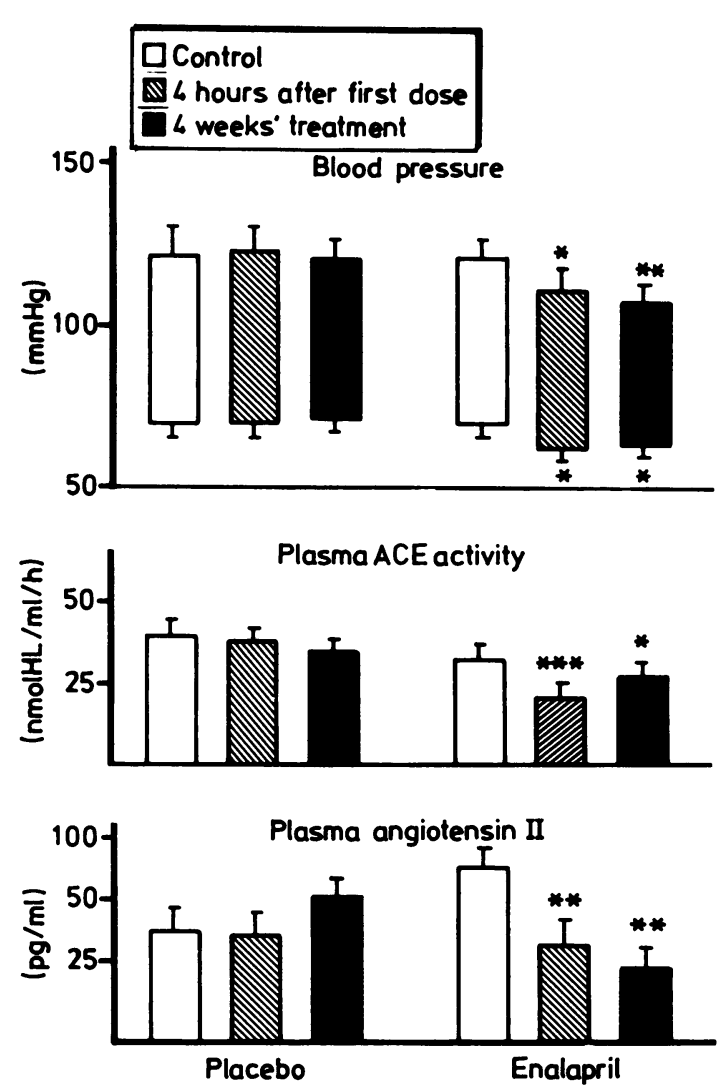

Fig. 1 Changes in supine blood pressure, plasma angiotensin converting enzyme activity ( $A C E$ ), and plasma angiotensin II concentrations after the first dose (4 hours) and during long term treatment (4 weeks) with placebo $(n=8)$ or enalapril $(n=10) .{ }^{\star} p<0.05,{ }^{\star}{ }_{p}<0.01$, $\star \star \star p<0.001$ compared with pretreatment result. $H L$, histidyl-leucine.

Table 4 Effects of enalapril treatment or placebo on responses to treadmill exercise (Naughton protocol) in cardiac failure (mean (SEM))

\begin{tabular}{|c|c|c|c|c|c|c|c|c|}
\hline & \multicolumn{4}{|c|}{ Enalapril (wk) } & \multicolumn{4}{|l|}{ Placebo } \\
\hline & -2 & 0 & 4 & 12 & -2 & 0 & 4 & 12 \\
\hline $\begin{array}{l}\text { No } \\
\text { Exercise duration (s) } \\
\text { Heart rate (beats/min): }\end{array}$ & $\begin{array}{l}13 \\
548(56)\end{array}$ & $\begin{array}{l}13 \\
577(46)\end{array}$ & $\begin{array}{l}13 \\
582(52)\end{array}$ & $\begin{array}{l}11 \\
607(49)\end{array}$ & $\begin{array}{l}12 \\
514(53)\end{array}$ & $\begin{array}{c}12 \\
532(59)\end{array}$ & $\begin{array}{l}12 \\
550(56)\end{array}$ & $\stackrel{7}{584(59)}$ \\
\hline $\begin{array}{l}\text { Pre-exercise } \\
\text { Exercise }\end{array}$ & $\begin{array}{r}92(6) \\
134(8)\end{array}$ & $\begin{array}{r}99(6) \\
139(8)\end{array}$ & $\begin{array}{l}88(4)^{\star} \\
141(9)\end{array}$ & $\begin{array}{l}88(5)^{\star} \\
139(10)\end{array}$ & $\begin{array}{r}94(4) \\
124(5)\end{array}$ & $\begin{array}{r}94(5) \\
126(5)\end{array}$ & $\begin{array}{r}87(4) \\
128(5)\end{array}$ & $\begin{array}{r}84(8) \\
123(7)\end{array}$ \\
\hline $\begin{array}{l}\text { Systolic blood pressure: } \\
(\mathrm{mm} \mathrm{Hg})\end{array}$ & & & & & & & & \\
\hline $\begin{array}{l}\text { Pre-exercise } \\
\text { Exercise }\end{array}$ & $\begin{array}{l}123(7) \\
144(9)\end{array}$ & $\begin{array}{l}126(6) \\
142(7)\end{array}$ & $\begin{array}{l}111(6)^{\star} \\
131(7)^{\star}\end{array}$ & $\begin{array}{l}104(6)^{\star} \\
128(10)^{\star}\end{array}$ & $\begin{array}{l}124(6) \\
141(8)\end{array}$ & $\begin{array}{l}127(8) \\
149(11)\end{array}$ & $\begin{array}{l}123(6) \\
140(7)\end{array}$ & $\begin{array}{l}135(8) \\
153(8)\end{array}$ \\
\hline $\begin{array}{l}\text { Rate-response } \\
\text { product at end of } \\
\text { exerciset }\end{array}$ & $19 \cdot 4(1 \cdot 8)$ & $20 \cdot 0(1 \cdot 6)$ & $18 \cdot 6(1.6)^{\star}$ & $18 \cdot 8(2 \cdot 6)^{\star}$ & $17 \cdot 3(0 \cdot 9)$ & $17 \cdot 9(1 \cdot 1)$ & $17 \cdot 7(0 \cdot 9)$ & $18 \cdot 8(1.5)$ \\
\hline
\end{tabular}

${ }^{\star} \mathrm{p}<0.05$ compared with week 0 .

tHeart rate $\times$ systolic blood pressure $\left(\times 10^{3}\right)$. 
Table 5 Changes in plasma noradrenaline ( $\mathrm{pmol} / \mathrm{ml}$ ) with exercise

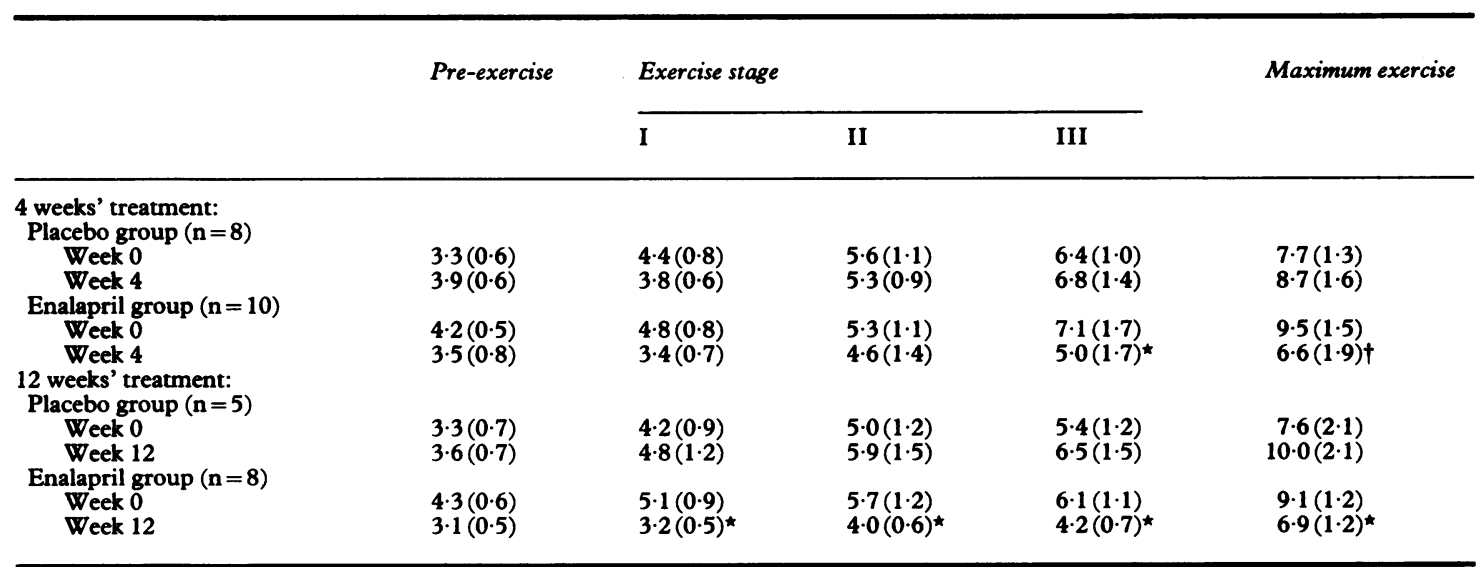

${ }^{\star} \mathrm{p}<0.05 ; \mathrm{tp}<0.02$ for treatment versus corresponding control (week 0 )

Conversion: $1 \mathrm{pmol} / \mathrm{ml}=1 \mathrm{nmol} / 1$.

until limiting symptoms of dyspnoea and fatigue or both occurred. There were no significant changes in exercise duration for either group (Table 4). After 4 weeks of enalapril treatment pre-exercise heart rate (88(4) beats per minute) and both pre-exercise (111(6) $\mathrm{mm} \mathrm{Hg}$ ) and maximum exercise (131(7) $\mathrm{mm}$ $\mathrm{Hg}$ ) systolic blood pressures were significantly lower (all $\mathrm{p}<0.05$ ) than pre-treatment control values (99(6) beats per minute; $126(6)$ and $142(7) \mathrm{mm} \mathrm{Hg}$ respectively). The rate and pressure product (heart rate $x$ systolic blood pressure) at the end of exercise, which was calculated as an indirect index of myocardial oxygen consumption, was significantly reduced after four and 12 weeks on enalapril $(p<0.05)$. There were no significant changes in any of these measurements in the placebo treated group (Table 4).

Before treatment (week 0) plasma noradrenaline concentrations increased progressively in response to increasing workload and the changes were similar in the placebo and enalapril groups (Table 5). After four and 12 weeks of treatment the noradrenaline responses to graded exercise in the placebo group did not differ at any workload from those observed in the pre-treatment control period. In contrast, the enalapril group had reduced noradrenaline responses to exercise at both four and 12 weeks. At four weeks the plasma noradrenaline concentrations at stage III and at maximum exercise were significantly lower than for the corresponding pretreatment control values (stage III $5 \cdot 0(1 \cdot 7)$ vs $7.7(1.3) \mathrm{pmol} / \mathrm{ml}, \mathrm{p}<0.05)$; maximum exercise 6.6(1.9) vs 9.5(1.5) pmol $/ \mathrm{ml}, \mathrm{p}<0.02)$. At 12 weeks plasma noradrenaline concentrations at each stage of exercise were all significantly lower $(p<0.05)$ than those observed during the pre-treatment control exercise test (Table 5).

$\begin{array}{lrr}\text { CHANGES IN } & \text { PLASMA } & \text { ENALAPRILATE } \\ \text { CONCENTRATIONS } & \text { AND } & \text { ANGIOTENSIN }\end{array}$ CONVERTING ENZYME ACTIVITY WITH CHRONIC TREATMENT

In the placebo treated group enalaprilate was not detected in any plasma sample and plasma angiotensin converting enzyme activity did not change significantly. Expressed as percentage of control (week 0) concentrations, angiotensin

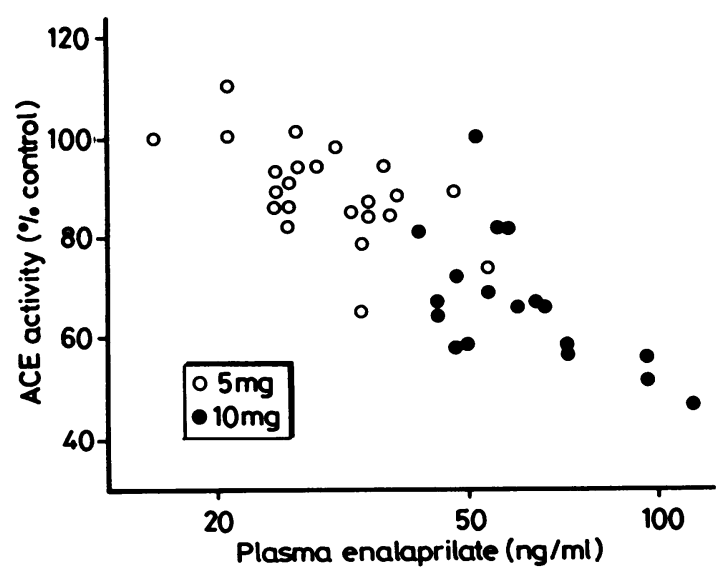

Fig. 2 Relation between log plasma enalaprilate and percentage angiotensin converting enzyme ( $A C E$ ) activity $(r=-0.66, n=41, p<0.001)$ in patients on $5 \mathrm{mg}$ enalapril twice a day and in patients on $10 \mathrm{mg}$ enalapril twice a day. 


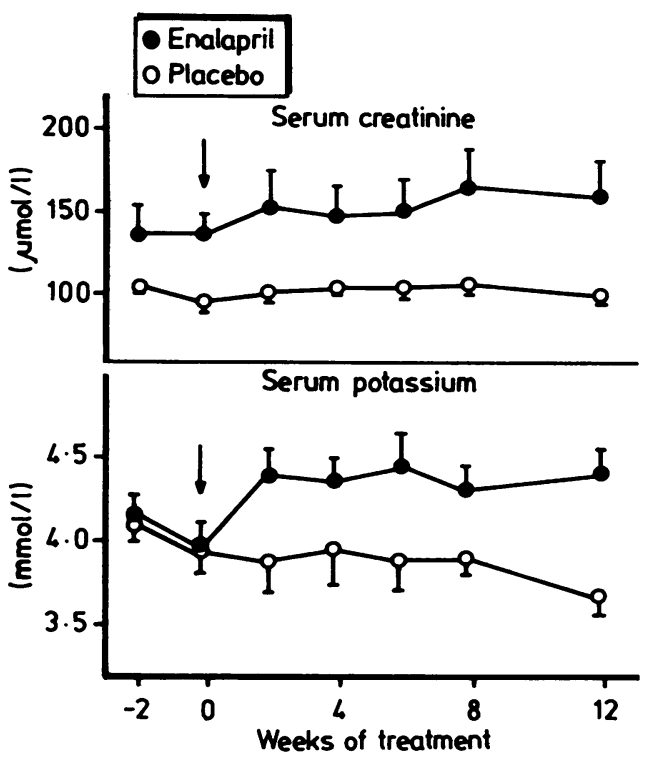

Fig. 3 Changes in plasma potassium and creatinine concentrations during long term enalapril treatment $(n=11)$ or placebo $(n=7)$. Results are expressed as mean ( $\pm S E M)$. The changes in both potassium and creatinine in the enalapril group are significant (analysis of variance: $F_{6,60}=2.98,2.49 ; p<0.025, p<0.05$ respectively).

converting enzyme activity at week 4 was $94(6) \%$ $(n=8)$ and at week 12 it was $92(9) \%(n=5)$. In eight patients in the enalapril group, treatment for two weeks resulted in plasma enalaprilate concentrations of $33(4) \% \mathrm{ng} / \mathrm{ml}$ and a reduction in converting enzyme activity to $82(5) \%$. After four weeks the results were similar (enalaprilate $32(3) \mathrm{ng} / \mathrm{ml}$; angiotensin converting enzyme activity $83(4) \%$ of control values). In five of these patients the dose of enalapril was increased to $10 \mathrm{mg}$ twice daily. After two and four weeks this resulted in increased concentrations of plasma enalaprilate (56(5), 66(8) $\mathrm{ng} / \mathrm{ml}$ ) and greater angiotensin converting enzyme inhibition (61(5), 67(6)\% of control values). Plasma concentrations of enalaprilate showed a significant linear correlation with plasma angiotensin converting enzyme activity $(r=-0.66, n=41$, $\mathrm{p}<0.001)$. The analysis showed that there was a clear separation in the responses to the two dose regimens used (Fig. 2).

CHANGES IN PLASMA POTASSIUM AND CREATININE

There were significant differences between the groups for changes in plasma concentrations of potassium and creatinine (Fig. 3). The placebo treated group showed no significant changes in either plasma potassium or creatinine concentrations. In the enalapril treated group there was a significant rise in plasma potassium $\left(\mathrm{F}_{6,60}=2.98\right.$, $\mathrm{p}<0.025)$. This was evident by two weeks and the increase was maintained for the duration of treatment. A slight rise in plasma creatinine was also observed $\left(F_{6,60}=2.49, p<0.05\right)$, the maximum change being observed after six weeks of treatment (167(25) vs 138(12) $\mu \mathrm{mol} / \mathrm{l}, \mathrm{n}=11, \mathrm{t}=-1.79$, $\mathrm{p}<0 \cdot 10$ ).

There were no significant changes in haemoglobin, white blood cell count, or platelet count in either group over the 12 weeks of observation.

\section{Discussion}

The results of this study suggest that enalapril is superior to placebo when added to digoxin and diuretic therapy in patients with moderate to severe heart failure. There was an improvement in the symptoms of fatigue and shortness of breath in most enalapril treated patients but in only one of the 12 placebo treated patients. There was also a significant difference between the groups for the numbers of patients who had worsening heart failure as assessed by a change in their New York Heart Association functional class $(1 / 13(8 \%)$ of the enalapil group versus $7 / 12(58 \%)$ of the placebo group).

In this study the clinical improvement in enalapril treated patients occurred without any significant changes in exercise duration or cardiac ejection fraction. This contrasts with a recent trial in which an increase in both of these measurements was reported after 12 weeks in enalapril treated but not in placebo treated patients. ${ }^{27}$ The design of that study, however, was different because diuretic therapy was varied according to symptoms and signs of cardiac failure, whereas in our study all treatments other than the test drug was kept constant. This may have contributed to the different results observed.

The reduced noradrenaline response to graded exercise was objective evidence for a beneficial effect during enalapril treatment. The precise stimulus for activation of the sympathoadrenal system during exercise is not well understood. In patients with heart failure studied during exercise, however, plasma noradrenaline concentration has been shown to correlate well with the degree of left ventricular failure and pulmonary artery oxygen saturation. ${ }^{28} 29$ Francis et al have recently reported an exaggerated plasma noradrenaline response to exercise in patients with heart failure when they were compared with normal subjects for equivalent levels of total 
body oxygen consumption. ${ }^{30}$ In our patients plasma noradrenaline concentrations increased markedly at low levels of workload. This response was considerably attenuated during enalapril treatment but was unchanged during placebo treatment when compared with the respective pre-treatment control responses. The mechanism for this reduced response during enalapril therapy is unclear. It is unlikely to be due to impairment of autonomic reflexes since the available evidence suggests that reflex function is maintained during converting enzyme inhibition. ${ }^{31}$ Indeed sympathetic responsiveness has been reported to improve on captopril treatment. ${ }^{32}$ The decrease in plasma noradrenaline concentrations at the very modest exercise levels achieved by our patients suggests reduced sympathetic activation due to an improvement in heart failure. The complex interactions between the renin-angiotensin and sympathetic system, however, provide the alternative explanation of reduced sympathetic drive secondary to reduced angiotensin II concentrations. Whatever the mechanism, a reduction in sympathetic activity may be beneficial.

The rate-pressure product has been reported to correlate well with myocardial oxygen consumption. ${ }^{33}$ Reduction in this index has been reported during an acute study with captopril. ${ }^{34}$ In the present study the rate-pressure product at maximum exercise was significantly reduced at four and 12 weeks in the enalapril group but not in the placebo group. The lower mean rate-pressure product during long term therapy in the active treatment group could not be attributed to a lower workload since exercise duration and maximum heart rate at four and 12 weeks were no different from either of the two pre-treatment control measurements. This is further evidence for haemodynamic improvement during enalapril treatment.

Enalapril appears to be well tolerated. Only one patient experienced a mild symptomatic hypotensive response to the first $5 \mathrm{mg}$ dose. Indeed it was not possible for an observer at the bedside to tell from the acute response to the first dose whether the patient had received enalapril or placebo. Our previous experience with captopril, admittedly in an open trial, suggests that the acute effects of $12.5 \mathrm{mg}$ of that drug are more readily discerned from the patients' responses. ${ }^{935}$ This may be because as captopril is a shorter acting drug it has a greater immediate effect or perhaps because the initial $5 \mathrm{mg}$ dose of enalapril is rather low. Nevertheless this dose of enalapril did produce significant falls in blood pressure and heart rate. There was also evidence, from the falls in plasma angiotensin converting enzyme activity and angiotensin II concentrations, for in vivo inhibition of converting enzyme. A significant reduction in plasma noradrenaline concentration was also observed, confirming other preliminary results with enalapril ${ }^{3637}$ and in accord with the results of other studies of captopril in cardiac failure. ${ }^{11}$ The importance of having a placebo control group when examining these hormonal responses is emphasised by examining the acute changes in plasma renin and noradrenaline (Table 2 ). In the placebo group there were reductions in plasma renin and noradrenaline concentrations although only the plasma renin changes were significant. These changes would be consistent with prolonged rest.

An advantage of angiotensin converting enzyme inhibitors is their ability to block secondary hyperaldosteronism and thus maintain normal serum potassium concentrations particularly in the face of potent diuretic therapy. This has been noted with captopril therapy in patients with hypertension ${ }^{38}$ and cardiac failure. ${ }^{11}$ In the present study there was a significant increase in plasma potassium in the enalapril treated group; no change occurred in the placebo group. None of the patients was receiving potassium supplements or potassium sparing diuretics, both of which had been discontinued before entry to the study.

A potential disadvantage of angiotensin converting enzyme inhibitors is that they may impair renal glomerular function by reducing efferent arteriolar resistance via inhibition of intrarenal angiotensin II formation. Patients at risk are those with bilateral renal artery stenosis or stenosis in a solitary kidney. ${ }^{39}$ Patients with severe cardiac failure and low renal perfusion pressure are also potentially at risk. ${ }^{40}$ We have previously observed a rise in plasma creatinine in 11 of 35 patients $(31 \%)$ on long term captopril treatment for cardiac failure. ${ }^{35}$ In the present study enalapril treatment was associated with a slight rise in plasma creatinine, although in no case was it sufficient to require cessation of treatment.

No adverse effects were experienced in either group during chronic treatment. In particular we did not encounter any reactions such as rash or mouth ulceration. Ten patients continued on enalapril after the end of the trial. Three have since died (4, 15, 28 months). Seven patients have now been on enalapril treatment for 28-35 months and clinical improvement has been maintained with no side effects.

Analysis of plasma concentrations of the active drug, enalaprilate, revealed a clear dose relation such that patients on $20 \mathrm{mg}$ per day enalapril had significantly higher concentrations than those on 10 
mg per day. There was also a clear relation between plasma enalaprilate and percentage inhibition of plasma angiotensin converting enzyme activity during long term treatment. We have observed a similar relation in patients with essential hypertension. ${ }^{21}$ It is of interest that the acute fall in plasma angiotensin converting enzyme activity observed after a single oral dose of enalapril is not maintained on long term treatment and adequate long term inhibition of angiotensin converting enzyme activity required substantially higher blood concentrations of enalaprilate and therefore higher doses of enalapril. This suggests that the dose of enalapril may need to be adjusted upwards for long term treatment.

This study was supported by a grant in aid from the National Heart Foundation of Australia. Dr Arnolda was in receipt of a fellowship from the Life Insurance Medical Research Fund of Australia. The study was performed as part of a multinational trial and we thank Dr D Jeremy and Ms C Martin of Merck, Sharp and Dohme (Australia) for their assistance.

\section{References}

1 Gavras H, Faxon DP, Berkoben J, Brunner HR, Ryan TJ. Angiotensin converting enzyme inhibition in patients with congestive heart failure. Circulation 1978; 58: 770-6.

2 Davis R, Ribner HS, Keung E, Sonnenblick EH, LeJemtel TH. Treatment of chronic congestive heart failure with captopril, an oral inhibitor of angiotensin-converting enzyme. $N$ Engl $\mathcal{F}$ Med 1979; 301: 117-21.

3 Turini GA, Brunner HR, Gribic M, Waeber B, Gavras $H$. Improvement of chronic congestive heart-failure by oral captopril. Lancet 1979; i: 1213-5.

4 Ader R, Chatterjee K, Ports T, Brundage B, Hiramatsu B, Parmley W. Immediate and sustained hemodynamic and clinical improvement in chronic heart failure by an oral angiotensin-converting enzyme inhibitor. Circulation 1980; 61: 931-7.

5 Dzau VJ, Colucci WS, Williams GH, Curfman G, Meggs L, Hollenberg NK. Sustained effectiveness of converting-enzyme inhibition in patients with severe congestive heart failure. $N$ Engl $\mathcal{F}$ Med 1980; 302: 1373-9.

6 Levine TB, Franciosa JA, Cohn JN. Acute and longterm response to an oral converting-enzyme inhibitor, captopril, in congestive heart failure. Circulation 1980; 62: 35-41.

7 Awan NA, Evenson MK, Needham KE, Win A, Mason DT. Efficacy of oral angiotensin-converting enzyme inhibition with captopril therapy in severe chronic normotensive congestive heart failure. Am Heart f 1981; 101: 22-31.

8 Sharpe DN, Coxon RJ, Douglas JE, Long B. Low-dose captopril in chronic heart failure: acute haemodynamic effects and long-term treatment. Lancet 1980; ii: $1154-7$.

9 McGrath BP, Denham IM, Johnston CI. Clinical improvement and hormonal changes in severe cardiac failure after captopril treatment. Aust $N Z \mathcal{Y}$ Med 1981; 11: 639-44.

10 Captopril Multicenter Research Group. a placebocontrolled trial of captopril in refractory chronic congestive heart failure. $\mathcal{F} \mathrm{Am}$ Coll Cardiol 1983; 2: $755-63$.

11 Romankiewicz JA, Brogden RN, Heel RC, Speight TM, Avery GS. Captopril ('Capoten') in congestive heart failure. Current Therapeutics 1983; 5: 21-47.

12 Packer M, Medina N, Yushak M. Contrasting hemodynamic responses in severe heart failure: comparison of captopril and other vasodilator drugs. Am Heart F 1982; 104: 1215-23.

13 Arnold SB, Williams RL, Ports TA, et al. Attenuation of prazosin effect on cardiac output in chronic heart failure. Ann Intern Med 1979; 91: 345-9.

14 Packer M, Meller J, Medina N, Yushak M, Gorlin R. Hemodynamic characterization of tolerance to longterm hydralazine therapy in severe chronic heart failure. $N$ Engl f Med 1982; 304: 57-62.

15 Walsh WF, Greenberg BH. Results of long-term vasodilator therapy in patients with refractory congestive heart failure. Circulation 1981; 64: 499-505.

16 Hichens M, Hand EL, Mulcahy NS. Radioimmunoassay for angiotensin converting enzyme inhibitor. Ligand Quarterly 1981; 4: 43-7.

17 Ulm NH, Hichens M, Gomez HJ, et al. Enalapril maleate and a lysine analogue (MK521): deposition in man. Br f Clin Pharmacol 1982; 14: 357-62.

18 New York Heart Association. The Criteria Committee. Nomenclature and criteria for diagnosis of diseases of the heart and great vessels. 8th ed. Boston: Little, Brown, 1979: 290.

19 Fortuin NJ, Hood WP Jr, Craige E. Evaluation of left ventricular function by echocardiography. Circulation 1972; 46: 26-35.

20 Kalff V, Kelly MJ, Jennings GL, et al. The radionuclide assessment of left ventricular function using graded exercise in normal subjects. Aust $N Z \mathcal{F}$ Med 1980; 10: 533-9.

21 Johnston CI, Jackson B, McGrath B, Matthews PG, Arnolda L. Relationship of antihypertensive effect of enalapril to serum MK422 levels and angiotensin converting enzyme inhibition. fournal of Hypertension 1983; 1 (suppl 1): 71-5.

22 Hörtnagl H, Benedict CR, Grahame-Smith DG, McGrath B. A sensitive radioenzymatic assay for adrenaline and noradrenaline in plasma. $\mathrm{Br} \mathcal{f}$ Clin Pharmacol 1977; 4: 553-8.

23 Johnston CI, Mendelsohn FAO, Casley DJ. Plasma renin determination employing a radioimmunoassay for angiotensin I. Proc Aust Soc Med Res 1969; 2: 271.

24 Boyd GW, Landon J, Peart WS. The radioimmunoassay of angiotensin II. Proc $R$ Soc Lond [Biol] 1969; 173: 327-38.

25 Cushman DW, Cheung HS. Spectrophotometric assay and properties of the angiotensin converting enzyme of 
rabbit lung. Biochem Pharmacol 1971; 20: 1637-48.

26 Snedecor GW, Cochran WG, eds. Statistical methods, 6th ed. Ames: Iowa State University Press, 1969: 258-98.

27 Sharpe DN, Murphy J, Coxon R, Hannan SF. Enalapril in patients with chronic heart failure: a placebo-controlled randomized, double-blind study. Circulation 1984; 70: 271-8.

28 Hansen JF, Christensen NJ, Hesse B. Determinants of coronary sinus noradrenaline in patients with ischaemic heart disease. Coronary sinus catecholamine concentration in relation to arterial catecholamine concentration, pulmonary artery oxygen saturation and left ventricular end-diastolic pressure. Cardiovasc Res 1978 ; 12: 415-21.

29 Thomas JA, Marks BH. Plasma norepinephrine in congestive heart failure. Am $\mathcal{f}$ Cardiol 1978; 41: 233-43.

30 Francis GS, Goldsmith SR, Ziesche SM, Cohn JN. Response of plasma norepinephrine and epinephrine to dynamic exercise in patients with congestive heart failure. Am f Cardiol 1982; 49: 1152-6.

31 Millar JA, Derkx FHM, McLean K, Reid JL. Absence of reflex tachycardia during converting enzyme inhibition: evidence against impairment of autonomic reflexes. Br $\mathcal{F}$ Clin Pharmacol 1982; 14: 129p-30p.

32 Cody RJ. The effect of captopril on postural hemodynamics and autonomic responses in chronic heart failure. Am Heart $\mathcal{F}$ 1982; 104: 1190-96.

33 Amsterdam EA, Mason DT. Exercise testing and indirect assessment of myocardial oxygen composition in evaluation of angina pectoris. Cardiology 1977; 62: 174-89.

34 Awan NA, Mason DT. Vasodilator therapy of severe congestive heart failure: the special importance of angiotensin-converting enzyme inhibition with captopril. Am Heart $\mathcal{F}$ 1982; 104: 1127-36.

35 McGrath BP, Johnston CI. Captopril in the treatment of hypertension in: new directions: angiotensin converting enzyme inhibition in cardiovascular medicine. Exerpta Medica Asia Pacific Congress Series 1983; $21: 29-42$.

36 DiCarlo L, Chatterjee $\mathrm{K}$, Atherton B, Curran D, Parmley W. MK421: a new angiotensin converting enzyme inhibitor in chronic heart failure: neurohumoral correlates of the haemodynamic response to acute and chronic therapy. Clin Res 1982; 30: 775A.

37 Fitzpatrick D, Nicholls MG, Ikram H, Espiner EA. Haemodynamic, hormonal and electrolyte effects of enalapril in heart failure. Br Heart $\mathcal{F} 1983$; 50: 163-9.

38 Johnston CI, McGrath BP, Miller JA, Matthews PG. Long-term effects of captopril (SQ14225) on bloodpressure and hormone levels in essential hypertension. Lancet 1979; ii: 493-6.

39 Hricik DE, Browning PJ, Kopelman R, Goorno WE, Madias NE, Dzau VJ. Captopril-induced functional renal insufficiency in patients with bilateral renal-artery stenoses or renal-artery stenosis in a solitary kidney. $N$ Engl f Med 1983; 308: 373-6.

40 Blythe WB. Captopril and renal autoregulation. $N$ Engl f Med 1983; 308: 390-1. 